\title{
Correlations of planktonic bioluminescence with other oceanographic parameters from a Norwegian fjord
}

\author{
David Lapota ${ }^{1}$, Mark L. Geiger ${ }^{2}$, Arthur V. Stiffey ${ }^{3}$, Dena E. Rosenberger ${ }^{4}$, \\ David K. Young ${ }^{3}$ \\ ${ }^{1}$ Naval Ocean Systems Center, Radiation Physics Branch, Code 524, San Diego, California 92152-5000, USA \\ ${ }^{2}$ Naval Oceanographic Office, Code OWSL, Stennis Space Center, Mississippi 39522-5004, USA \\ ${ }^{3}$ Naval Ocean Research \& Development Activity, Oceanography Division, Code 333, Stennis Space Center, Mississippi \\ 39522-5004, USA \\ ${ }^{4}$ Computer Sciences Corporation, 4045 Hancock Street, San Diego, California 92110, USA
}

\begin{abstract}
In August 1985 and 1986, a series of bathyphotometric measurements were made in icefree waters of Vestfjord, Norway, to quantify stimulable in situ bioluminescence. In 1986, we tested and identified the causative bioluminescent plankton. In all profiles, peak or maximum bioluminescence intensity was always within a zone of 15 to $30 \mathrm{~m}$ below sea surface, with marked decreases below $50 \mathrm{~m}$. Maximum bioluminescence intensity from all profiles for both years ranged from $3 \times 10^{8}$ to $2 \times 10^{9}$ photons $\mathrm{s}^{-1} \mathrm{CC}^{-1}$ of turbulently-flowing seawater. Testing some of the plankton on board ship revealed that the brightest flashes were produced by the copepods Metridia longa and $M$. Iucens and the ostracod Conchoecia sp. Dinoflagellates of the genus Protoperidinium emitted light at an intermediate level. The total number of dinoflagellates ranged from 1300 to 3700 cells $1^{-1}$ at water depths of 10 to $30 \mathrm{~m}$, and sharply decreased at 80 to $100 \mathrm{~m}$ (2 to 11 cells $\left.\mathrm{l}^{-1}\right)$. It was estimated that dinoflagellates accounted for $96 \%$ of the measured light from the surface to a depth of $100 \mathrm{~m}$. Several species of the luminous dinoflagellate Ceratium were found. However, their contribution to the overall light budget never exceeded $25 \%$. P. curtipes contributed at least $50 \%$ of the measured light field at $30 \mathrm{~m}$ and above. In general, luminous zooplankton (larval copepods and euphausiids) contributed less than $4 \%$ of the light produced above $100 \mathrm{~m}$. The number of bioluminescent dinoflagellates correlated with bioluminescent intensity at the 0.05 significance level. Correlation analysis of beam attenuation coefficient with bioluminescent intensity yielded thigh $r$ values resulting in an overall level of significance of less than 0.01 , and, therefore, may be a useful indicator for bioluminescence
\end{abstract}

\section{INTRODUCTION}

An essential element needed to predict the distribution of planktonic bioluminescence in any ocean area is knowing which species are producing the light. However, this, and other, basic information is often lacking. For example, while intensity and distribution of luminescence have been investigated and measured since the 1960's in a variety of oceans, very little has been done at latitudes above the arctic circle in icecovered and ice-free waters.

In 1985 and 1986, in the ice-free waters of the Vestfjord, Norway, we had the opportunity to measure in situ bioluminescence with submersible bathyphotome- ters. We were also able to test and identify the plankton responsible for the measured bioluminescence in 1986.

A time series of bathyphotometer profiles (bioluminescence, optical transmission, seawater temperature) was conducted in August 1985 while additional stations were studied in late August 1986. The later studies focused on bioluminescence, optical transmission, seawater temperature, chlorophyll a fluorescence, and plankton abundance relationships. These investigations provided us not only with the opportunity to document the variability of the bioluminescence intensity and other parameters in a fjord but also allowed us to determine which plankton were responsible for the bioluminescence. 


\section{STUDY AREA}

The study area was at the mouth of the Vestfjord on the coast of western Norway above the Arctic Circle between $13^{\circ}$ and $15^{\circ}$ east longitude (Fig. 1). The Vestfjord is a deep, high-latitude estuary; water depths range from $620 \mathrm{~m}$ at the head to $144 \mathrm{~m}$ at the sill. The fjord is more than $150 \mathrm{~km}$ long and is $70 \mathrm{~km}$ wide at the mouth. The characteristics of the Vestfjord hydrography reflect the diversity of contributing water masses. Water from a branch of the Norwegian Coastal Current impinges on outflow from the fjord. In general, coastal waters flow into the fjord along the southeast side, turn westward, and flow seaward with the colder, outflowing fjord water Winds exert a dominant influence on circulation patterns. Southwest winds set up Ekman transport away from the coast with associated upwelling along the western side of the fjord. Northeasterly winds along the same coast cause net transport out of the fjord (Furnes \& Sundby 1981).

Three water masses within the fjord have been described (Furnes \& Sundby 1981). The cold, homogeneous surface layer may be as deep as $150 \mathrm{~m}$ with a salinity of 33 to 34 parts per thousand (ppt). Below this mixed layer lies a 10 to $50 \mathrm{~m}$ thermocline where temperature increases from 4 to $6.5^{\circ} \mathrm{C}$. The deep-water layer is of Atlantic origin and has a temperature of 6.5 to $7^{\circ} \mathrm{C}$ and a salinity of 34.7 to $35 \mathrm{ppt}$. Warming of surface waters in the summer causes a seasonal thermocline and a shallow mixed layer with temperatures ranging from 10 to $15^{\circ} \mathrm{C}$

In August 1986, 4 stations were investigated, 2 in the mouth of the Vestfjord ( 2 and 3 ) and 2 along the eastern margin of the fjord north of Landegodefjord (1 and 4). Station work was also conducted near the latter stations in August 1985 and is included for comparison.

\section{MATERIALS AND METHODS}

In 1986, bioluminescence, optical transmission, seasurface water temperature, and chlorophyll a fluorescence were measured with a submersible bathyphotometer (Lapota \& Losee 1984). In 1985, a similar bathyphotometer was used to measure the same parameters exclusive of chlorophyll fluorescence (Losee et al. 1984). The submersible bathyphotometer system pumped plankton-laden seawater past an RCA 8575 photomultiplier tube (PMT) operating in the single photon-count mode which measured light through a filter wheel with a capacity for carrying 10 optical filters. Neutral density filters of varying attenuation (factors of 10 and 1000) complemented the filter set. All components were contained in an aluminum pressure housing. A $1 / 3 \mathrm{hp}$ Gould submersible pump (Model 10 EJ) with a flow rate of $0.8 \mathrm{I} \mathrm{s}^{-1}$ was mounted on the exterior of the detector to pull seawater through a viewing chamber fitted with an ultraviolet transmitting window. A light-tight $10 \mathrm{~cm}$ i.d. s-shaped plastic black pipe was used to convey seawater into the detector which abruptly narrowed down into an arm of the viewing chamber The sudden reduction in pipe size introduced turbulence and maintained a constant stimulus for the plankton being viewed.

Signal pulses from the PMT of the stimulated bioluminescence were recorded in several modes. Con-

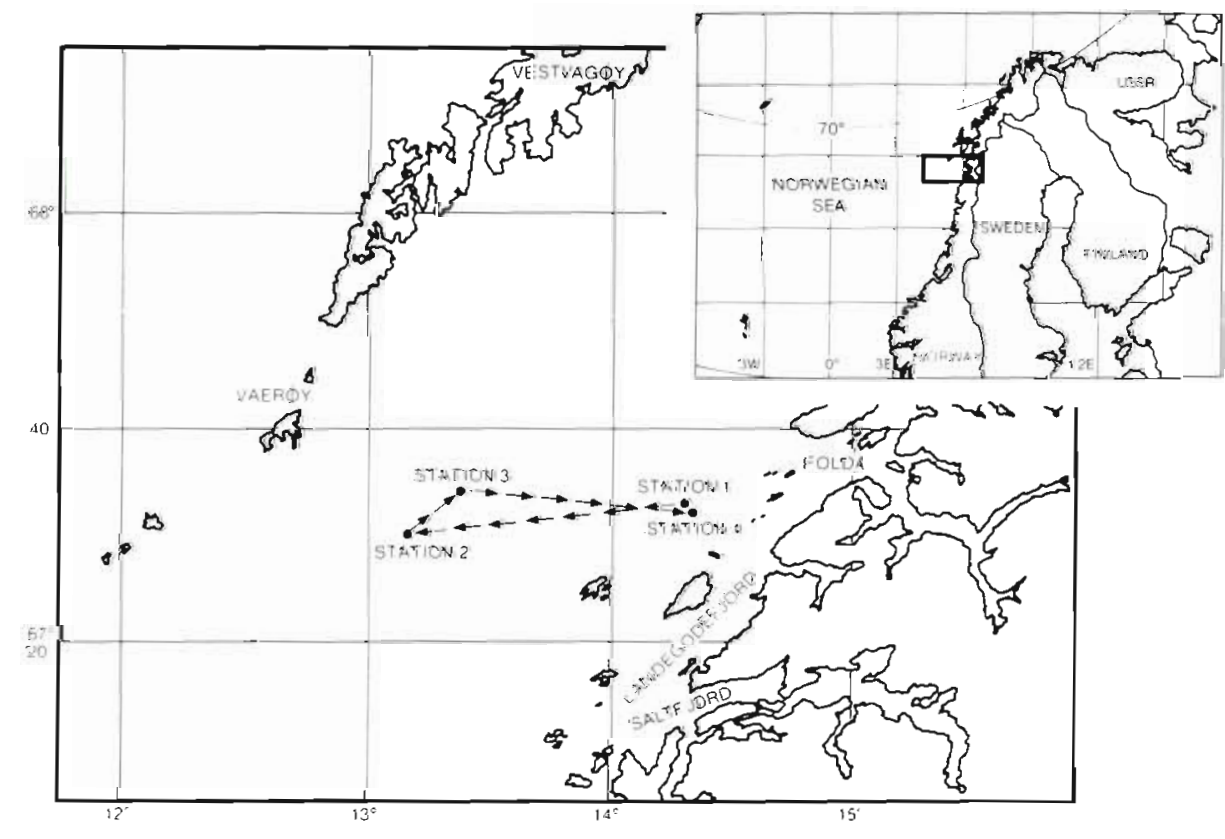

Fig. 1. Boxed area designates study area and station location in the Vestfjord, Norway 
tinuous 30 s sample blocks were obtained with an Ortec scaler (Model 874) and recorded as an accumulated count on an Otrona microcomputer. High time resolution data of the bioluminescence signal were obtained by bringing the PMT signal pulses into time channels of $10 \mathrm{~ms}$ on a Davidson multichannel analyzer (Model 1056). The data were recorded in 1023 channel blocks on the microcomputer

Optical light transmission (T) was measured using a Sea Tech $0.25 \mathrm{~m}$ beam transmissometer with an LED that emitted at $680 \mathrm{~nm}$ mounted vertically on the bathyphotometer. Transmission (T) was converted to beam attenuation coefficient $(c=-\ln T / 0.25 \mathrm{~m})$. Beam attenuation measures the attenuation of a highly collimated beam of light and is used as a measurement of both absorption and scattering from all particulate matter in the water (dinoflagellates, diatoms, marine snow, other debris). Temperature was measured using a Sea Bird temperature sensor (Model SBE-3) mounted directly on the bathyphotometer. A $2.5 \mathrm{~cm}$ i.d. hose from the bathyphotometer's pumping system delivered seawater to the laboratory of the ship for the measurement of in vivo chlorophyll a fluorescence and the collection of plankton samples. A Turner Designs (Model 10-005R) fluorometer measured fluorescence and the data were reported in relative units. The detector package was deployed down to depths of ca $100 \mathrm{~m}$.

Plankton samples from the bathyphotometer were collected by diverting effluent from the hose to the shipboard plankton collection tank. Plankton samples (each representing $45 \mathrm{l}$ of seawater) were collected in $20 \mu \mathrm{m}$ collection cups from the bathyphotometer effluent at each station during the ascent from 100,50, $40,30,20$, and $10 \mathrm{~m}$ depths. A vertical plankton net tow ( $1 / 2 \mathrm{~m}$ ring, $2 \mathrm{~m}$ length, $500 \mu \mathrm{m}$ net and collection cup) accompanied bathyphotometric measurements from each of the 4 stations from 100 to $0 \mathrm{~m}$ (1986 measurements). Plankton samples were washed into sample jars with filtered seawater and preserved in $5 \%$ buffered formalin seawater solution. Single phyto- and zooplankters were isolated from plankton tows and individually tested for bioluminescence in the laboratory plankton test chamber (LPTC). To facilitate this testing, isolated organisms were placed into quartz sample holders with $6 \mathrm{ml}$ filtered $(0.45 \mu \mathrm{m})$ seawater. The lucite base of the sample holders was pre-drilled to accommodate water removal by an applied vacuum. Whatman GF/C filters lined the bottoms of the holders to retain the test organism following water removal. To observe the luminescence, an RCA 8575 photomultiplier tube was mounted onto the test chamber port. The output of the PMT (high time resolution) was displayed as a time sequence of counts ( $40 \mathrm{~ms}$ time channels) from the induced flash. The 'instantaneous' intensity of the signal is proportional to the number of counts in each channel (Lapota \& Losee 1984). Recovery of luminous plankters was accomplished by repeated washings of the sample vial with filtered seawater into a glass dish for later identification.

The luminescent 'isolate' data identified which dinoflagellate and crustacean zooplankter species contributed to the measured bioluminescence. All pumped bathyphotometer plankton samples and vertical net tows were analyzed for species composition and numerical abundance. Each sample was completely examined for zooplankton while the dinoflagellate component was enumerated by settling subsamples of seawater and examining with an inverted microscope at $100 \times$ magnification. A light budget for the luminous plankton collected from the bathyphotometer and from plankton net tows was calculated based on average light output values recorded from individual bioluminescent plankters. This method of analysis has been described for bioluminescent plankton collected from the Arabian Sea (Lapota et al. 1988b).

\section{RESULTS AND DISCUSSION}

\section{Bioluminescence intensity and structure in 1986}

Two vertical bioluminescence profiles were recorded at each of the 4 stations from 28 to 31 August, 1986. All profile measurements were conducted during the night from 1944 to 2319 (Z) h. For a given profile, the lowering rate was held as constant as possible, but among all profiles the lowering rates ranged from $6 \mathrm{~m} \mathrm{~min}^{-1}$ to $10.7 \mathrm{~m}$ $\min ^{-1}$ which corresponds to a vertical spatial sampling resolution of 3.0 to $5.4 \mathrm{~m}$. Bioluminescent structure and intensity were similar at all stations. Peak or maximum bioluminescence intensity was always within a zone of 15 to $30 \mathrm{~m}$ depth (Fig. 2). Maximum bioluminescence intensity from all profiles ranged from $3 \times 10^{8}$ to $2 \times 10^{9}$ photons $\mathrm{s}^{-1} \mathrm{cc}^{-1}$, comparable to the high intensities measured in the Arabian Sea (Lapota et al. 1988b). The Arabian Sea is considered to have some of the brightest known bioluminescent displays. Peak bioluminescence intensity at all 4 stations varied by less than a factor of 3 . The bioluminescence intensity observed near a depth of 90 to $100 \mathrm{~m}$ for all profiles ranged from $3 \times 10^{6}$ to $4 \times 10^{7}$ photons $\mathrm{s}^{-1} \mathrm{CC}^{-1}$ of seawater.

In all profiles, the beam attenuation coefficient increased within the peak bioluminescence layer and decreased below that. In many of the profiles, the thermocline appeared to be associated with all or part of the maximum bioluminescence layer. Chlorophyll a fluorescence values were greatest near the bottom of the maximum bioluminescence layer and in some cases appeared to correlate with structure within the lumi- 

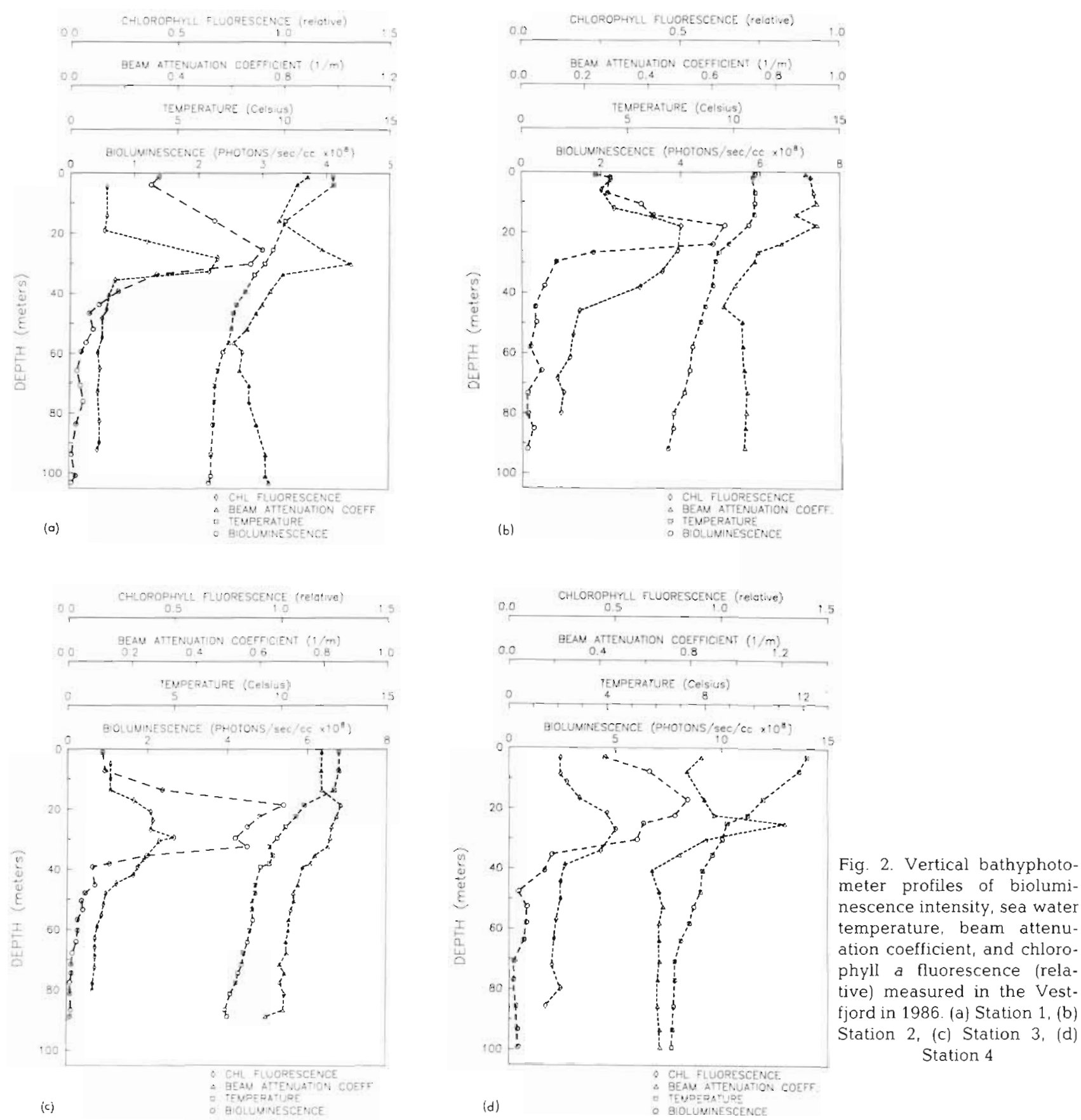

nescent layer. The increase in beam attenuation within portions of the luminescent layer may have been reflective of the increased numbers of dinoflagellates and diatoms

\section{Bioluminescence intensity and structure in August 1985}

Two profiles obtained on 18 August 1985, at depths to $75 \mathrm{~m}$, resembled the 1986 profiles. Maximum

bioluminescence was centered from 17 to $21 \mathrm{~m}$ below the sea surface and had an intensity of $1 \times 10^{9}$ photons $\mathrm{s}^{-1} \mathrm{Cc}^{-1}$ (Fig. 3a). Fourteen other vertical profiles (to depths of $50 \mathrm{~m}$ ) were obtained during 18 to 20 August 1985, from 22:30 to $05: 00 \mathrm{~h}$. Of these profiles, only one will be presented to highlight differences (Fig. 3b). The pattern of bioluminescence distribution for these latter profiles was different from those exhibited at the first 2 stations in 1985 and all stations measured in 1986. The peak layer structure was distributed over a greater depth and was not sharply defined as in 1986 profiles. 

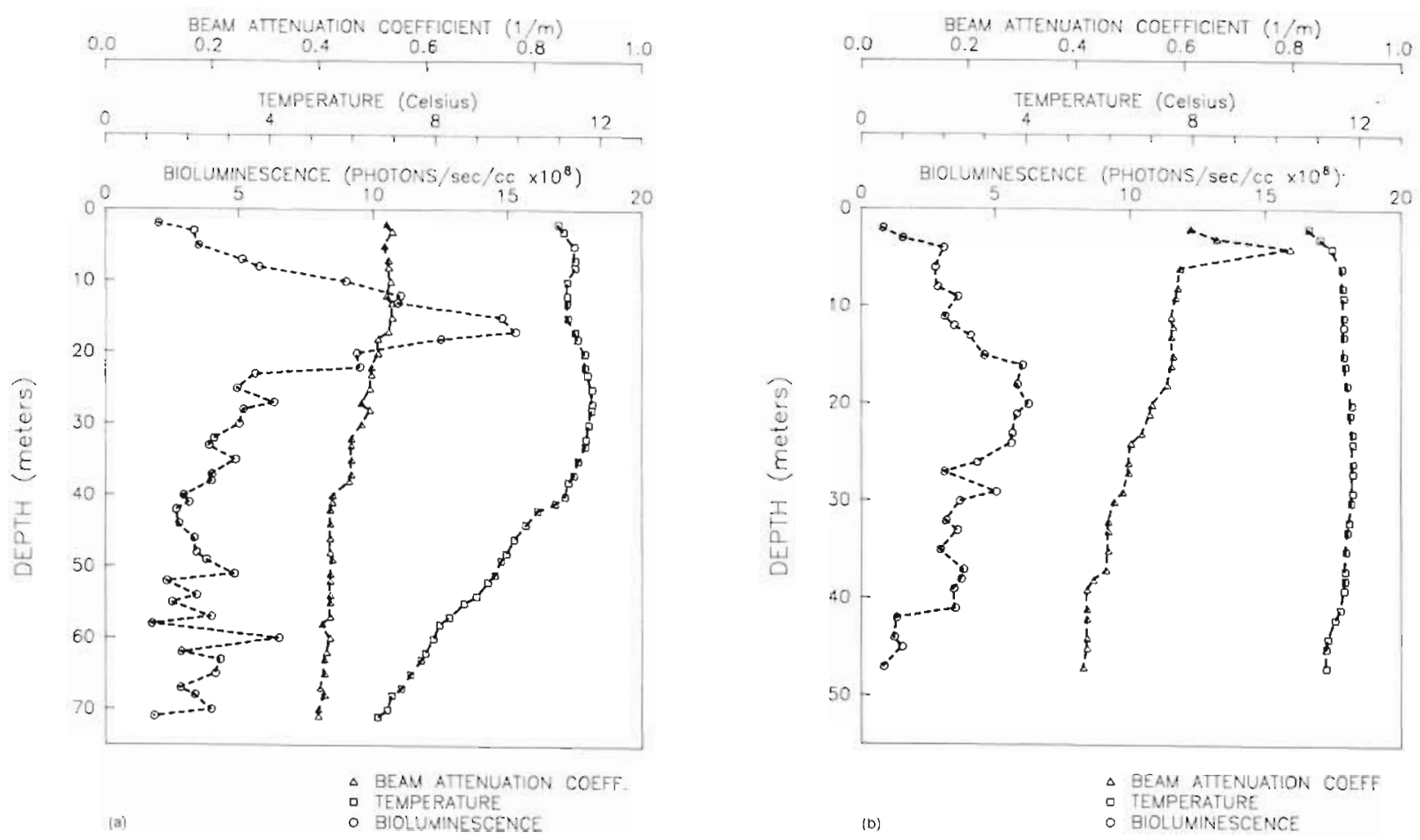

Fig. 3. Vertical bathyphotometer profiles of bioluminescence intensity, seawater temperature, and beam attenuation coefficient in the Vestfjord in 1985. (a) Measured near Station 1, (b) Station 4

Peak intensity and peak layers were still found within the ranges measured in 1986 (15 to 30 rn below the sea surface). The temperature structure in all 1985 profiles was different from that observed the following year. The 1985 profiles indicated a more homogeneous temperature distribution throughout and a slight warming trend in the deep, well-mixed surface layer in contrast to the seasonal thermocline and shallow mixed layer measured at the 1986 stations.

The similarities and differences in bioluminescence and temperature structure between the 1985 and 1986 data raised the question of the driving mechanism which controlled these relationships. Studies show that vertical structure can vary with wind conditions on relatively short time scales as the thermocline rises and falls with upwelling and downwelling (Furnes \& Sundby 1981). In a study of the Masfjord, western Norway, during June and October 1985, advective water flow influenced by wind-forcing strongly affected the vertical biomass structure of phytoplankton and zooplankton (Aksnes et al. 1989). The 1985 Vestfjord profiles were taken during a time of strong winds. If wind serves as a major physical force in determining dinoflagellate distributions in the Vestfjord, then for future studies a bathyphotometer time series taken before, during, and after such events could address the effect that turbulence has on cell layering and the time needed to form these layers. Luminous copepod dis- tribution, too, may have been layered. In order to define their vertical structure, a series of openingclosing net measurements could be undertaken to more closely approximate their true spatial distribution in the water column and impact on the local light budget.

\section{Observations of plankton in August 1986}

The plankton samples from the bathyphotometer effluent were enumerated and sorted. The total number of dinoflagellates among all 4 stations ranged from ca 100 to 3700 cells $\mathrm{l}^{-1}$ of seawater at 10 to $30 \mathrm{~m}$ and sharply decreased to a range of 2 to 12 cells $1^{-1}$ at 80 to $100 \mathrm{~m}$ (Fig. 4). At $20 \mathrm{~m}$, total dinoflagellates (including luminous and non-luminous species) averaged 1600 cells $l^{-1}$. Below the thermocline, dinoflagellate numbers decreased abruptly.

Although very abundant, dinoflagellates of the genus Ceratium are among the dimmest planktonic light producers. However, luminescence was not observed in cells of $C$. fusus and $C$. furca in this study. Bioluminescence has been observed in these species from other studies (Nordli 1957. Sweeney 1963, Gold 1965, Kelly \& Katona 1966, Tett 1969, Lapota \& Losee 1984). Dinoflagellates of the genus Protoperidinium are reported to emit light at an intermediate intensity (Hardy \& Kay 1964, Kelly \& Katona 1966, Tett 1969, 


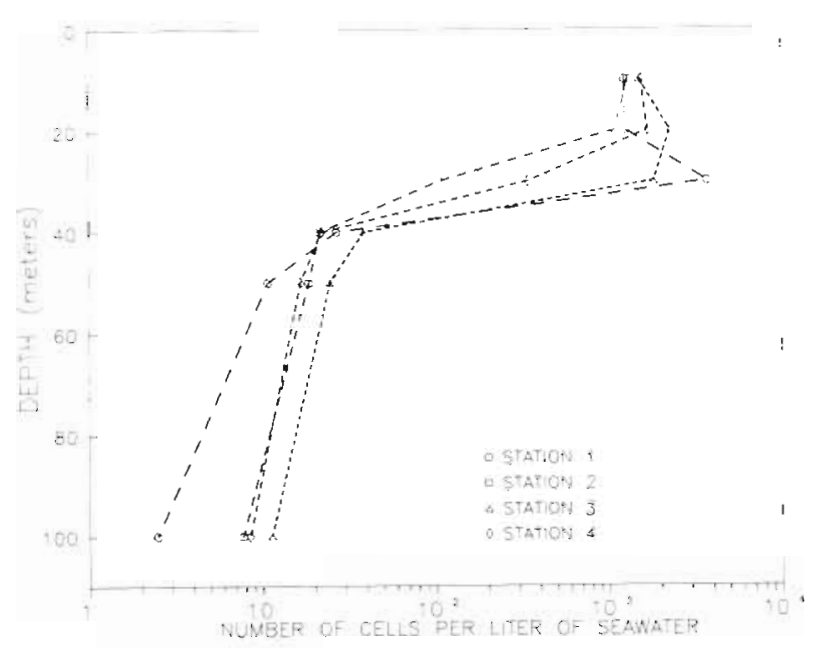

Fig. 4. Total number of dinoflagellates at the water depths indicated, 1986

1971, Lapota \& Losee 1984, Lapota et al. 1988b) (Fig. $5 \mathrm{a})$. The observation of luminescence in $P$. curtipes Jorgensen (1913) in this study is new (Table 1, Fig. 5b), although luminescence has been observed in the closely related species $P$. crassipes Kofoid (Filimonov et al. 1982, M. Kelly pers. comm.).

Non-luminous diatoms were represented by species of Coscinodiscus, Corethron, and Rhizosolenia. Peak distributions of diatoms at 3 of the stations were found in the upper $20 \mathrm{~m}$ and ranged from 59 to $1973 \mathrm{cells}^{-1}$ (Fig. 6). The depth at which the peak number of diatom cells occurred corresponded to peak dinoflagellate cell distributions. Stations 1 and 4 were dominated by Coscinodiscus $\mathrm{sp}$. while Station 2 was dominated by Corethron sp. Below $30 \mathrm{~m}$, the number of diatoms decreased to a few cells $\mathrm{l}^{-1}$.

Zooplankton assemblages in the bathyphotometer samples were variable in occurrence. Calanoid nauplii were abundant in all samples. The luminescent copepod nauplii Metridia longa (Lapota et al. 1988a) were rare, usually less than $11^{-1}$, and $M$. longa and $M$. lucens were infrequent (Table 2). This is consistent with the fact that these copepods were never found in numbers exceeding $3 \mathrm{~m}^{-3}$ seawater from the vertical net hauls at all stations. Analysis of some of the collected plankters revealed that some of the brightest flashes were produced by $M$. longa and $M$. lucens, the ostracod Conchoecia elegans, and the euphausiid Thysanoessa sp. (Fig. 7). All of these brightly luminescent crustaceans were collected in the net tows but sampled less frequently by the detector (Table 2). The non-luminous copepod Calanus finmarchicus was found in all net tows, but was appreciably less abundant at Station 1. The greatest numbers of luminescent crustaceans were found at Station 2.

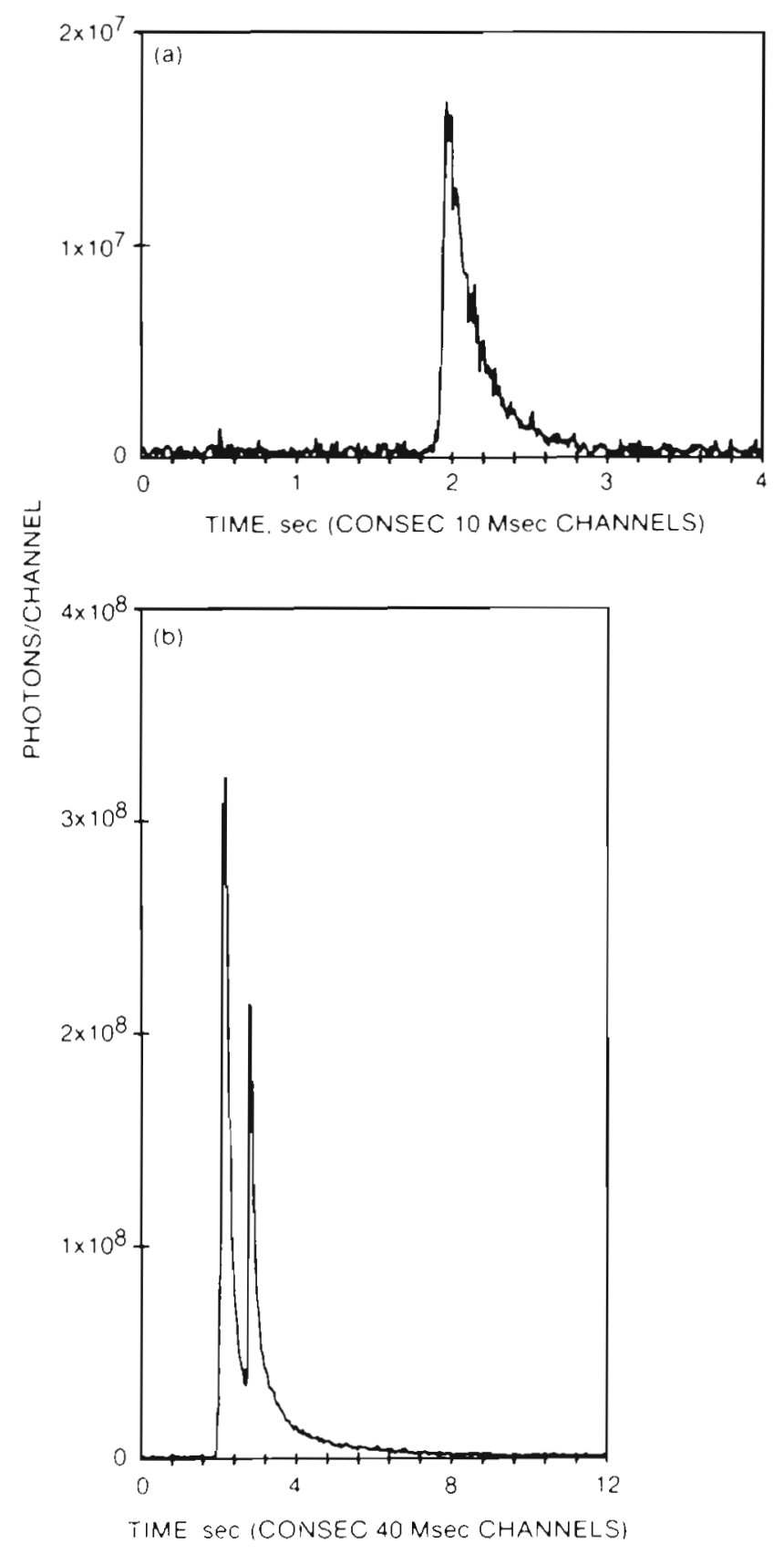

Fig. 5. High time resolution scans of flashes emitted from Protoperidinium depressum and $P$. curtipes collected in net tows from the Vestfjord in 1986; $y$ axis = flash intensity (photons per $10 \mathrm{~ms}$ or $40 \mathrm{~ms}$ channels). (a) The armored dinoflagellate $P$. depressum emitted ca $3.5 \times 10^{8}$ photons in this flash, Aug 31, 1986; (b) the armored dinoflagellate P. curtipes, a dommant dinoflagellate found at all stations, emitted ca. $4.6 \times 10^{9}$ photons in this flash, Aug 31, 1986

High time resolution scans of the luminescent plankton viewed by the bathyphotometer indicate significant differences in intensity and frequency of events at various depths at all 4 stations (Fig. 8). Generally, the number of bioluminescent events decreased with depth 
Table 2. Plankton composition (number of individuals) of vertical net tows (500 $\mu \mathrm{m}$ mesh net and collection cup) 100 to $0 \mathrm{~m}$ collected at Stations 1 to 4 in 1986

\begin{tabular}{|c|c|c|c|c|c|c|c|}
\hline Zooplankton & Station & Total & $\begin{array}{l}\text { Per cubic } \\
\text { meter }\end{array}$ & Zooplankton & Station & Total & $\begin{array}{l}\text { Per cubic } \\
\text { meter }\end{array}$ \\
\hline Calanus finmarchicus & $\begin{array}{l}1 \\
2 \\
3 \\
4\end{array}$ & $\begin{array}{r}675 \\
4871 \\
3416 \\
3238\end{array}$ & $\begin{array}{r}22 \\
154 \\
83 \\
67\end{array}$ & Oithona helgolandica & $\begin{array}{l}1 \\
2 \\
3 \\
4\end{array}$ & $\begin{array}{r}11 \\
11 \\
7 \\
5\end{array}$ & $\begin{array}{l}<1 \\
<1 \\
<1 \\
<1\end{array}$ \\
\hline Metridia longa" & $\begin{array}{l}1 \\
2 \\
3 \\
4\end{array}$ & $\begin{array}{r}1 \\
105 \\
43 \\
69\end{array}$ & $\begin{array}{r}<1 \\
3 \\
1 \\
1\end{array}$ & $\begin{array}{l}\text { Thysanoessa sp." } \\
\text { Nyctiphanes sp. }\end{array}$ & $\begin{array}{l}2 \\
4 \\
2 \\
4\end{array}$ & $\begin{array}{r}4 \\
11 \\
3 \\
5\end{array}$ & $\begin{array}{l}<1 \\
<1 \\
<1 \\
<1\end{array}$ \\
\hline Sagitta sp. & $\begin{array}{l}3 \\
4\end{array}$ & $\begin{array}{r}5 \\
36\end{array}$ & $\begin{array}{r}<1 \\
1\end{array}$ & Hyperia & $\begin{array}{l}2 \\
3\end{array}$ & $\begin{array}{l}4 \\
3\end{array}$ & $\begin{array}{l}<1 \\
<1\end{array}$ \\
\hline Metridia lucens & $\begin{array}{l}1 \\
2 \\
3 \\
4\end{array}$ & $\begin{array}{r}3 \\
31 \\
3 \\
19\end{array}$ & $\begin{array}{r}<1 \\
1 \\
<1 \\
<1\end{array}$ & $\begin{array}{l}\text { Evadne } \\
\text { Ophiopluteus } \\
\text { Zoea }\end{array}$ & $\begin{array}{l}1 \\
1 \\
1\end{array}$ & $\begin{array}{l}4 \\
3 \\
1\end{array}$ & $\begin{array}{l}<1 \\
<1 \\
<1\end{array}$ \\
\hline Centropages elegans & $\begin{array}{l}3 \\
4\end{array}$ & $\begin{array}{r}17 \\
4\end{array}$ & $\begin{array}{l}<1 \\
<1\end{array}$ & Pteropod & 2 & 1 & $<1$ \\
\hline Conchoecia elegans" & 4 & 13 & $<1$ & $\begin{array}{l}\text { Larvacean } \\
\text { Microsetella sp. }\end{array}$ & $\begin{array}{l}1 \\
4\end{array}$ & $\begin{array}{l}1 \\
1\end{array}$ & $\begin{array}{l}<1 \\
<1\end{array}$ \\
\hline
\end{tabular}
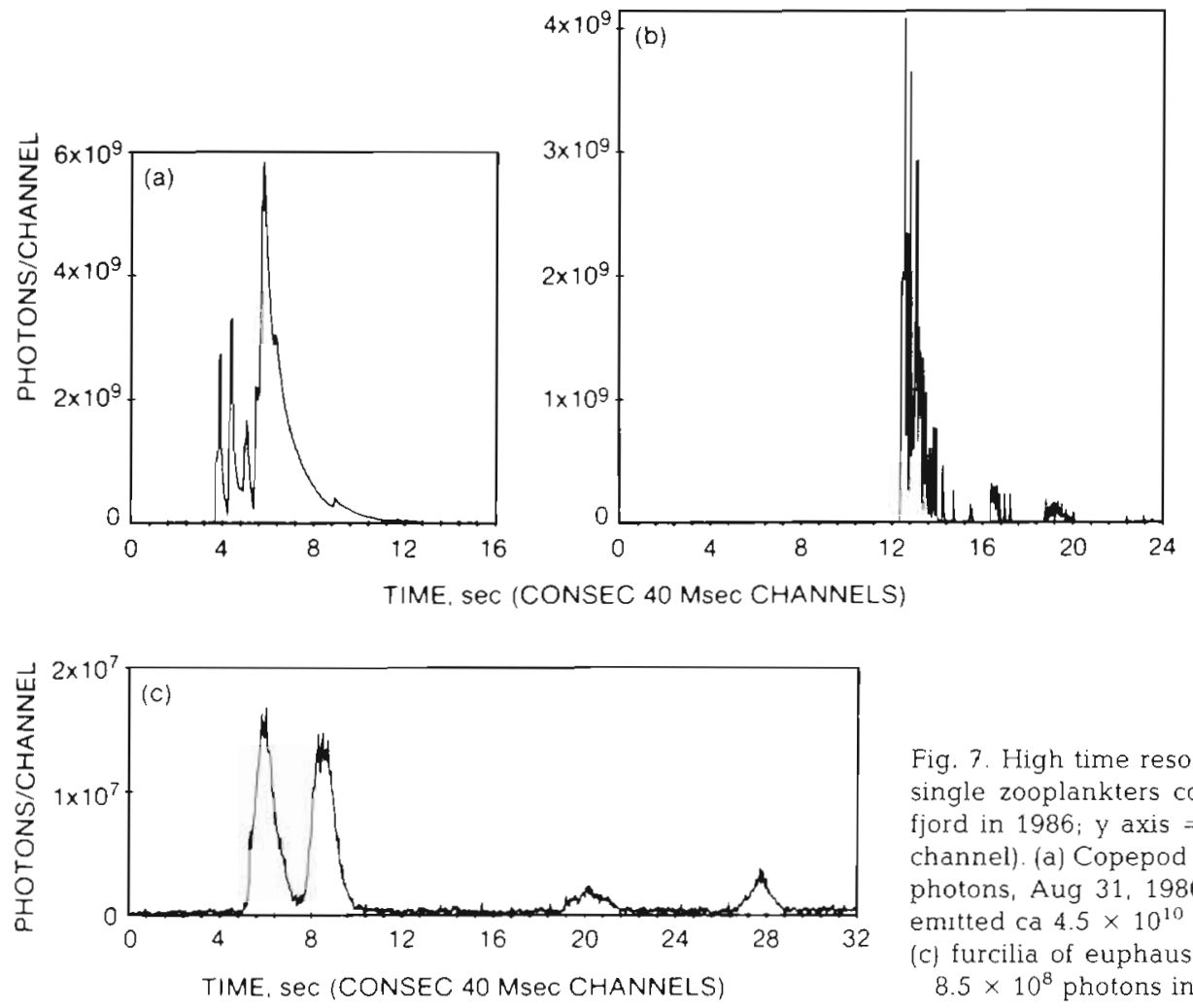

Fig. 7. High time resolution scans of flashes emitted from single zooplankters collected in net tows from the Vestfjord in 1986; y axis = flash intensity (photons per $40 \mathrm{~ms}$ channel). (a) Copepod Metridia longa emitted ca $2.1 \times 10^{11}$ photons, Aug 31, 1986; (b) ostracod Conchoecia elegans emitted ca $4.5 \times 10^{10}$ photons in this flash, Aug 31, 1986; (c) furcilia of euphausiid Thysanoessa inermis emitted ca $8.5 \times 10^{8}$ photons in the 2 larger peaks, Aug 31, 1986 




Fig. 8. High time resolution scans of bioluminescent events at Station 4 at depth recorded with the bathyphotometer (A-D). All scans were of a $10 \mathrm{~s}$ duration; $y$ axis = bioluminescence intensity (photons per $10 \mathrm{~ms}$ channel). (a) Bioluminescence events at $10 \mathrm{~m}$; (b) bioluminescence events reached a peak in frequency and intensity at $20 \mathrm{~m}$; (c) bioluminescence decreased at $30 \mathrm{~m}$; at $40 \mathrm{~m}$ (d), the frequency of events was markedly less

genus Ceratium into the light budget (upper limit) did not significantly affect the percentage of light contributed by Protoperidinium spp. dinoflagellates. Assuming that the Ceratium were luminescent (hundreds of cells $\mathrm{l}^{-1}$ at the shallower depths), their contribution to the overall light budget never exceeded $25 \%$, while P. curtipes still contributed at least $50 \%$ of the measured light field at $30 \mathrm{~m}$ and above.

The few luminous copepods (Metridia longa and $M$. lucens) found from the net tows $(100$ to $0 \mathrm{~m}$ ) did not alter the light budget with respect to the plankton collected from the effluent of the bathyphotometer.

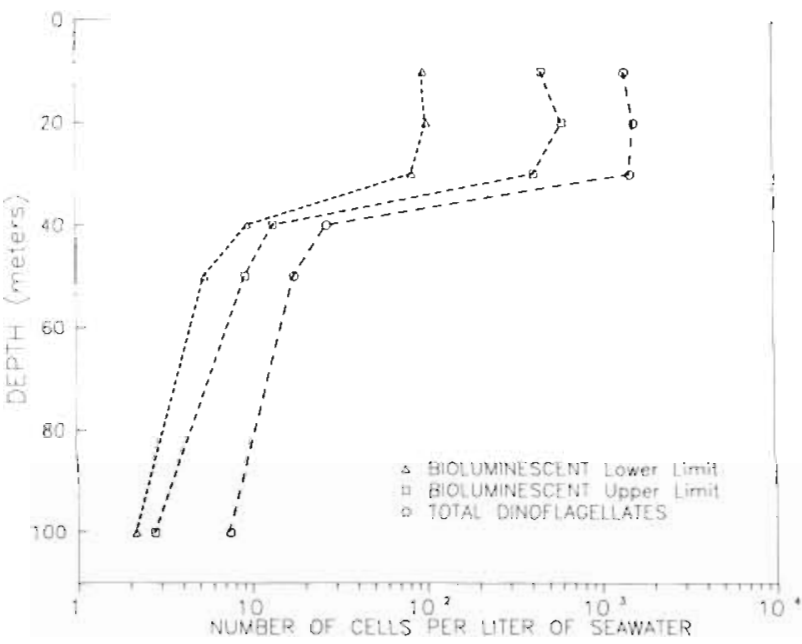

Fig. 9. Mean number of total and bioluminescent dinoflagellates at the depths indicated for Stations 1 to 4,1986
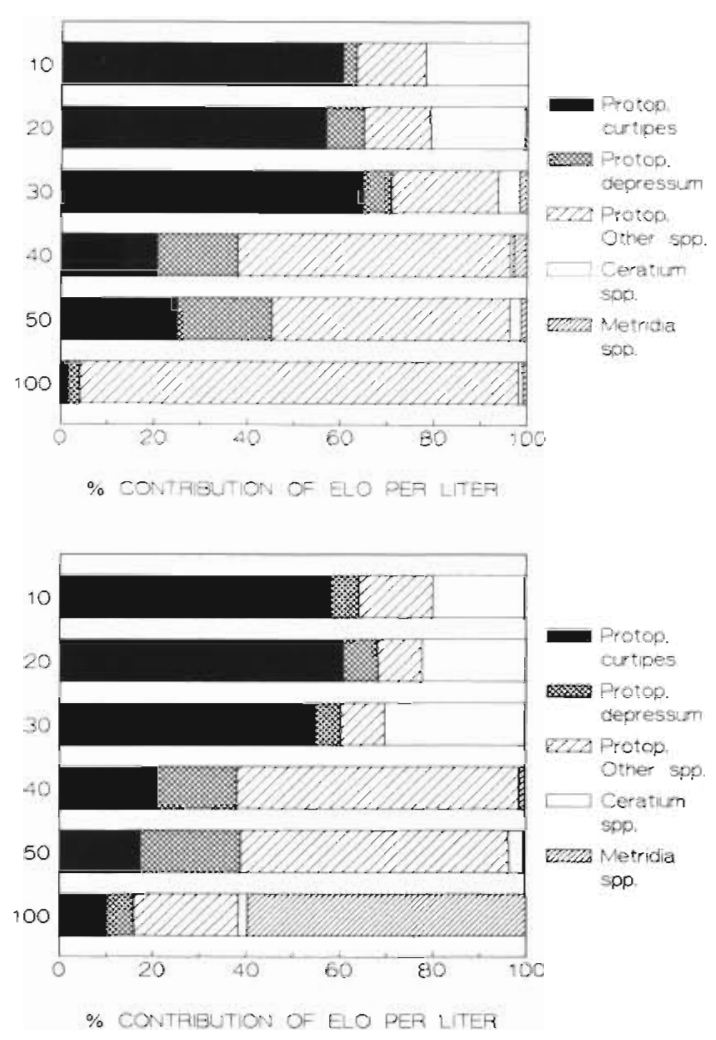

Fig. 10. Light budget breakdown (upper limit) for Stations 2 and 4 . Breakdown presented as percent contribution of estimated light output (ELO) per liter of seawater by dinoflagellates of the genera Protoperidinium and Ceratium and by the copepods Metridia spp. Upper: Station 2; lower: Station 4

\section{Correlations among measured parameters}

Bioluminescence, chlorophyll a fluorescence, beam attenuation, and dinoflagellate cell number data were 
Table 3. Correlation analysis for bioluminescence (photons $\mathrm{s}^{-1} \mathrm{cc}^{-1}$ ) versus number of dinoflagellate cells per liter seawater at Stations 1 to 4 , Vestfjord, $1986 . r=$ correlation coefficient; $p=$ significance level (alpha level)

\begin{tabular}{|c|c|c|c|c|c|c|}
\hline \multirow[t]{2}{*}{ Station } & \multicolumn{2}{|c|}{ Total dinoflagellates } & \multicolumn{2}{|c|}{$\begin{array}{l}\text { Bioluminescent } \\
\text { dinoflagellates } \\
\text { (upper limit) }\end{array}$} & \multicolumn{2}{|c|}{$\begin{array}{l}\text { Bioluminescent } \\
\text { dinoflagellates } \\
\text { (lower limit) }\end{array}$} \\
\hline & $\mathrm{r}$ & $\mathrm{p}$ & $r$ & $\mathrm{p}$ & $\mathrm{r}$ & $\mathrm{p}$ \\
\hline 1 & 0.860 & 0.05 & 0.964 & 0.01 & 0.691 & $>0.10$ \\
\hline 2 & 0.925 & 0.01 & 0.929 & 0.01 & 0.930 & 0.01 \\
\hline 3 & 0.932 & 0.01 & 0.963 & 0.01 & 0.953 & 0.01 \\
\hline 4 & 0.889 & 0.02 & 0.961 & 0.01 & 0.890 & 0.02 \\
\hline
\end{tabular}

collected and analyzed for all stations. Scatter plots of the data revealed that possible linear correlations existed and, subsequently, correlation analyses were performed on these parameters. Since plankton samples were taken discretely $(10,20,30,40,50$, and $100 \mathrm{~m}$ ), correlations utilizing cell numbers had an $n=6$. This assumes depths are replicates of the same linear relationship of the 2 variables being correlated. Sample depths (for cell number analysis) were matched with data from the continuous vertical profiles (bioluminescence, fluorescence, and beam attenuation) at the closest depth (within $2 \mathrm{~m}$ or by extrapolating between 2 data points if the data were too widely spaced). Other correlations had various in values due to slight variations in bathyphotometer descent rate.

The correlation coefficient ( $r$ ) values for bioluminescence intensity versus number of dinoflagellates (Table 3) ranged from 0.691 to 0.964 . With the exception of Station 1 (total dinoflagellates and lower limit bioluminescent dinoflagellates) these $r$ values reflected a high degree of correlation. For the upper limit bioluminescent dinoflagellates, correlations with bioluminescence intensity at all stations were significant at the 0.05 level. In the total and lower limit tests of Table 3, 3 out of the 4 stations exhibited correlations significant at the 0.05 level. These results were consistent with the light budget analysis.

In general, beam attenuation correlated less than bioluminescence with number of dinoflagellates. The I values at Stations 2 and $3(0.893<r<0.989)$ appeared to be higher than those for Stations 1 and $4(0.518<\mathrm{r}$ $<0.964)$. This lowered correlation could be expected since beam attenuation is a measure of all particulate matter in the water column. Maximum beam attenuation occurred in the upper $30 \mathrm{~m}$, coincident with peak intensity of bioluminescence and chlorophyll fluorescence.

Like beam attenuation, chlorophyll a fluorescence did not exhibit a high degree of correlation with numbers of dinoflagellates. In fact, the correlation analysis indicated that the overall significance level for each of the three sets of correlations is well above the 0.2 level. A possible explanation for this low observed correlation is that not all dinoflagellates contain chlorophyll pigments (i.e. Protoperidinium spp.). Although not included in the table, the number of diatoms found in the discrete samples also did not correlate with chlorophyll a fluorescence. This may be attributed to smaller, chlorophyll-bearing diatoms and micro-flagellates not retained by the $20 \mu \mathrm{m}$ mesh collection cups for counting and relative differences in fluorescence among the chlorophyll-bearing cells.

Correlation analysis of beam attenuation coefficient $\left(\mathrm{m}^{-1}\right)$ with bioluminescence intensity (photons $\mathrm{s}^{-1} \mathrm{Cc}^{-1}$ ) yielded high r values (Table 4 a) resulting in an overall level of significance of less than 0.01 ( $99 \%$ confidence).

Table 4. Correlation analyses; $\mathrm{r}=$ correlation coefficient; $\mathrm{p}=$ significance level (alpha level)

\begin{tabular}{|c|c|c|c|}
\hline Station & $r$ & $\mathrm{p}$ & $n$ \\
\hline 1 & 0.862 & 0.001 & 19 \\
\hline 2 & 0.792 & 0.001 & 18 \\
\hline 3 & 0.886 & 0.001 & 25 \\
\hline 4 & 0.779 & 0.001 & 17 \\
\hline
\end{tabular}

(b) Chlorophyll a fluorescence (relative units) versus bioluminescence (photons $\mathrm{s}^{-1} \mathrm{Cc}^{-1}$ )

\begin{tabular}{ccll} 
Station & $\mathrm{r}$ & $\mathrm{p}$ & $\mathrm{n}$ \\
\hline 1 & 0.670 & 0.01 & 14 \\
2 & 0.717 & 0.02 & 10 \\
3 & 0.843 & 0.001 & 19 \\
4 & 0.624 & 0.05 & 13
\end{tabular}

(c) Chlorophyll a fluorescence (relative units) versus beam attenuation coefficient $\left(\mathrm{m}^{-1}\right\}$

\begin{tabular}{cccc} 
Station & $r$ & $p$ & $n$ \\
\hline 1 & 0.740 & 0.01 & 14 \\
2 & 0.379 & $>010$ & 10 \\
3 & 0.832 & 0.001 & 19 \\
4 & 0.791 & 0.01 & 13 \\
\hline
\end{tabular}


In analyses of chlorophylla fluorescence with bioluminescence (Table 4 b) and beam attenuation (Table $4 \mathrm{c}$ ), however, only 3 out of 4 stations showed significance at the 0.05 level. These relationships may be reflective of the increasing numbers of chlorophyllbearing dinoflagellates (Ceratium spp.), diatoms co-occurring at the same depth, and heterotrophic bioluminescent dinoflagellates grazing on diatoms (Jacobson 1987). Other studies have found correlations between chlorophyll a fluorescence and bioluminescence on small spatial scales $(<10 \mathrm{~km})$ in the Gulf of California (Lieberman et al. 1987).

Because of the significant correlations between the aforementioned parameters, beam attenuation may be a useful indicator for bioluminescence. However, the relative contribution from all sources of light attenuation would have to be understood for a given water column before any generalization could be drawn on the usefulness of beam attenuation as a predictor of bioluminescence potential.

Acknowledgements. The authors thank captain and crew of the USNS 'Lynch' (T-AGOR 7) for making these measurements possible; Irene DePalma (NORDA Code 333) for technical assistance and discussions in the early phase of this project; and to Doug Huddell (NAVOCEANO Code OWSL) for kindly permitting us the use of a bathyphotometer plotting program. This manuscript was greatly improved by the comments and suggestions of Arthur Carpenter (CALOXY, Carlsbad, CA) and 3 anonymous reviewers. This work was supported by NSAP Task R-32-86 which is gratefully acknowledged

\section{LITERATURE CITED}

Aksnes, D. L., Aure, J., Kaartvedts, S., Magnesen, T., Richard, J. (1989). Significance of advection for the carrying capacities of Fjord populations. Mar Ecol. Prog. Ser. 50: 263-274

Filimonov, V S., Tyulkova, N. A., Sadovskaya, G. M. (1982) Luminescence of dinoflagellates by ultrasonic stimulation.

This article was presented by Dr O. Holm-Hansen, La Jolla, USA
In: Bioluminescence in the Pacific. Proc. 14th Pacif. Sci Congr Khabarovsk, USSR, 1979

Furnes, G. K., Sundby, S. (1981). Upwelling and wind induced circulation in Vestfjorden. In: The Norwegian coastal current. Norwegian Coastal Current Symposium, Geilo, Norway, Vol. 1 University of Bergen, p. 152-177

Gold, K. (1965). A note on the distribution of luminescent dinoflagellates and water constituents in Phosphorescent Bay, Puerto Rico. Ocean Sci. Ocean Engng 1: 77-80

Hardy, A. C., Kay, R. H. (1964). Experimental studies of plankton luminescence. J. mar. biol. Ass. U.K. 44: 435-486

Jacobson, D. M. (1987). The ecology and feeding behavior of thecate heterotrophic dinoflagellates. Doctoral dissertation. Woods Hole Oceanographic Institution, Woods Hole

Kelly, M. G., Katona, S. (1966). An endogenous diurnal rhythm of bioluminescence in a natural population of dinoflagellates. Biol. Bull. mar. biol. Lab. Woods Hole 131: $115-126$

Lapota, D., Bowman, T E., Losee, J. R. (1988a). Observations on bioluminescence in the nauplius of Metridia longa (Copepoda, Calanoida) in the Norwegian Sea. Crustaceana 54: 314-320

Lapota, D., Galt, C., Losee, J. R., Huddell, H. D., Orzech, J. K., Nealson, K. H. (1988b). Observations and measurements of planktonic bioluminescence in and around a milky sea. J. exp. mar Biol. Ecol. 119: 55-81

Lapota, D., Losee, J. R. (1984). Observations of bioluminescence in marine plankton from the Sea of Cortez. J. exp. mar. Biol. Ecol. 77. 209-240

Lieberman, S. H., Lapota, D., Losee, J. R., Zirino, A. (1987). Planktonic bioluminescence in the surface waters of the Gulf of California. Biol. Oceanogr. 4 (1): 25-46

Losee, J., Lapota, D., Geiger, M., Lieberman, S. (1984). Bioluminescence in the marine environment. In: Blizzard, M. (ed.) Ocean Optics VII. Proc. Soc. photo-opt. Instrmn Engrs 489: 77-98

Nordli, E. (1957). Experimental studies on the ecology of Ceratia. Oikos 8: 200-265

Sweeney, B. M. (1963). Bioluminescent dinoflagellates. Biol. Bull. mar biol. Lab., Woods Hole 125: 177-181

Tett, P. B. (1969). Study of marine bioluminescence. Final report. Scottish Marine Biological Association, Dunstaffnage Marine Research Laboratory, Oban

Tett, P. B. (1971). The relation between dinoflagellates and the bioluminescence of seawater J. mar biol. Ass. U. K. 51 183-206

Manuscript first received: February 25, 1989

Revised version accepted: May 11, 1989 